\title{
THE IMAGE OF PRINCE GEBANG IN BABAD SUTAJAYA MANUSCRIPT
}

\author{
ANWAR SANUSI, TENDI \\ Institut Agama Islam Negeri Syekh Nurjati Cirebon \\ e-mail: ucianwarsanusi@yahoo.com
}

\begin{abstract}
Prince Gebang was one of the local rulers who collaborated with the VOC at the end of the $17^{\text {th }}$ century. His domain, named as the Principality of Gebang (Kepangeranan Gebang), extended from the northern coastal area of Gebang Sea to the south side of the Cijolang River bordering on Galuh. Although the name of Sutajaya was clearly written as Prince Gebang (Pangeran Gebang) in the colonial archives, but his identity and his travel process towards the power of the Gebang area was not clearly explained. This article aimed to reveal the image of Prince Gebang through Babad Sutajaya manuscript stored in Pangeran (Prince) Pasarean Museum. Based on the ancient manuscripts, a number of essences related footage Sutajaya figure were taken to be analyzed. Historical elements contained in the affinity of the story were comparated to records of colonial archives and sources of oral traditions that still exist. From this study, it is known that Babad Sutajaya depicts the image of Prince Gebang as an important figure, who came from the royal court of Cirebon. In addition, this manuscript also illustrates Prince Gebang's abilities and reveals how he gained the territory of Gebang as his controlled area.
\end{abstract}

Keywords: Image, prince sutajaya, principality of gebang, babad, Royal Court of Cirebon

\section{GAMBARAN PANGERAN GEBANG DALAM MANUSKRIP BABAD SUTAJAYA}

\begin{abstract}
Abstrak
Pangeran Gebang adalah salah satu tokoh di wilayah setempat yang berkolaborasi dengan VOC pada akhir abad ke-17. Wilayah kekuasaannya, dinamai sebagai Kerajaan Gebang (Kepangeranan Gebang), membentang dari wilayah pesisir utara Laut Gebang ke sisi selatan Sungai Cijolang yang berbatasan dengan Galuh. Meskipun nama Sutajaya ditulis secara jelas sebagai Pangeran Gebang dalam arsip kolonial, tetapi identitas dan proses perjalanan hidupnya menuju kekuasaan wilayah Gebang tidak dideskripsikan dengan jelas. Penelitian ini berupaya untuk memberikan gambaran sosok Pangeran Gebang melalui naskah Babad Sutajaya yang disimpan di Museum Pangeran (Pangeran) Pasarean. Dari naskah kuno, diambil sejumlah esensi terkait cuplikan gambar Sutajaya untuk dipelajari. Unsur-unsur sejarah yang terkandung dalam afinitas cerita diperbandingkan dengan catatan arsip kolonial dan sumber-sumber tradisi lisan yang masih ada. Dari penelitian ini diketahui bahwa Babad Sutajaya menggambarkan citra Pangeran Gebang sebagai tokoh penting yang berasal dari istana kerajaan Cirebon. Selain itu, naskah ini juga menggambarkan kemampuan Pangeran Gebang dan mengungkapkan bagaimana ia mendapatkan wilayah Gebang sebagai daerah yang dikontrolnya.
\end{abstract}

Kata Kunci: Gambaran, pangeran sutajaya, kepangeranan gebang, babad, Kesultanan Cirebon

\section{INTRODUCTION}

In the historical study of Cirebon, a number of figures who had contribution to the development and expansion of this region were not closely known entirely, even recorded comprehensively. Many names such as Raden Fatahillah, Prince Sutajaya, Ki Bagus Serit, dr. Sudarsono and Captain
Samadikun, were some important figures in Cirebon who succeeded to carve history, but rarely became the topic of talk in the middle of wider community. It happened because of the lack of compilation, arrangement, and publication about their gait in the community. In fact, if their tracks in the course of history were recognized, the role and contribution 


\section{Anwar Sanusi, Tendi}

given was very large for both the context of the history of Cirebon and Archipelago.

The lack of study and effort in revealing the gait of the figures can be caused by two things, the problem of interest in study and limitedness of existing historical sources. Related to the scarcity of interest toward the study, it is possible because the theme is considered unattractive, not too significant, or has been considered irrelevant and less important by the reviewer so then abandoned. Meanwhile for the second problem, it happen because various historical sources which recorded the names of the characters were not too many, have not been discovered or may have not been found so that later the researchers concluded that the evidence supporting the gaits of the characters did not exist.

In the case of historical sources, evidence is the most important basis for a historian to reveal facts. In the eyes of historians, facts can be similar to the most important material for constructing the building of historical studies because the facts give us an idea of events, or about individuals who are present recently or existed in the past (Sjamsuddin, 2007). One of the proofs which can be used as a source in the historical study is the manuscript.

The manuscript is the most important medium in philology, which contains much information about civilizations in the past. In historical studies, the manuscript is commonly used as a form of source because it generally contains historical values that can be used as a source of information to build historical evidence and fact. Babad Cirebon and Carita Purwaka Caruban Nagari are two examples of ancient manuscripts used as a source for writing the history of Cirebon.

To do writing about the gaits of Cirebon's figure which are rarely published in the wider community, the author intend to use an ancient manuscript entitled Babad Sutajaya as one of the source to reveal the figure of Prince Gebang or Prince Sutajaya. Why should be the figure of Prince Sutajaya? Due to all the figures mentioned above, the name Sutajaya is almost forgotten in the historical process of Cirebon due to the journey of life and its role has not been recorded at all in an academic writing.

In fact, the noble elite who came from the Cirebon Palace (Kraton Cirebon) is one important figure in the process of territorial expansion of both Cirebon region and also Islam religion. In terms of territory, Sutajaya managed to tether the name of Cirebon to Galuh area, or which is recently known as the territory of Ciamis, in the area of East Priangan. In addition to his duty in expanding the influence and hegemony, Sutajaya also provided teaching and role model for religious issues so that later he was known as one of the spreaders of Islam in the area of Kuningan and Ciamis.

Prince Gebang was one of the local rulers who joined with the VOC at the end of the 17th century. His domain, named as the Kepangeranan Gebang, extended from the northern coastal area of Gebang Sea to the south side of the Cijolang River bordering on Galuh. Although the name of Sutajaya is clearly written as Prince Gebang in the colonial archives, his identity and process towards the power of Gebang area was not clearly demonstrated. Thus, this article would attempted to reveal the image of Prince Gebang through Babad Sutajaya manuscript stored in Prince Pasarean Museum. The contents of the manuscript would be examined and then taken a few of main points from citations to review the historical elements contained in its chonological story. Nevertheless, the records of the colonial archives and the source of the oral tradition would be used as a comparison of the narrations contained in the chronicle.

\section{RECOGNIZING THE FIGURE OF PRINCE GEBANG}

Discussing about Prince Gebang, it is important to be careful to see how the name was pinned to him. For his first name, "Prince" demonstrates a very high title of a noble title because the status of the prince is only one level below the king's position. The title of the prince was attributed to the male descendants of a ruler who had a monarchical government system, such as a king, sultan, or emperor. While the name Gebang refers to the name of an area located in the east of Cirebon. Thus, Prince Gebang is a title or mention that is pinned to the monarchist ruler in the area of Gebang. Despite having a territory and an independent power system, in this case, the status and level of Prince Gebang's powers were still under the control of Sultan Cirebon. The conferment of the territory was only borrowed to be processed, considering that the land rights at that time were absolute by the king. The possibility of granting such land was used instead of the salary to be paid for the performance given to the monarchy. In the former territory of Mataram, the land given to his relatives for such management was referred to as lungguh land. Area managers who had the duty to oversee the human and natural resources that exist there for the sake of the king 


\section{The Image of Prince Gebang in Babad Sutajaya Manuscript}

were called as patuh (Mubyarto, dkk., 1992).

According to the oral tradition developed in the middle of Gebang and surrounding communities, the name was referred to as Prince Gebang was Prince Sutajaya. The noble came from the palace of Cirebon pioneered and built Gebang area after he successfully completed the tasks assigned to him from the ruler of Cirebon. Gebang naming toward his authorization area, because the area was grown by many gebang (corypha utan) trees, a kind of palm trees that grow in the lowlands and have grains (Nursalam, 2017). While in the records of colonial archives, Prince Gebang was written with different names and mentions, although the intention for the same name, namely Sutajaya. For example, in the archive of the district list of 1686, it was written the name of Prince Gebang under the name Soetadjaya (Fernando, 2013). Then, in the certificate of agreement with the VOC at Benteng Bescherming in 1708, the writing of his name was Pangeran Aria Soetawijaja (Stapel, 1935).

Not much different from the source of the oral tradition and archive records, Babad Sutajaya also explicitly mentions that Prince Gebang is Sutajaya. The identity of the prince is written in the manuscript, as follows: “... sigegen malih kocapa / jeng pangéran / hing gebang turan pekik / kéngetan ning kadhang ngipun / salingsing pan wus sampurna / nulya medhal / karsané hayun nanjugjug / haniti turanggan ning wang / wasta jaran sambarani / tumurun sing ngawang-ngawang / sutajaya karsané nyandhak jemparing / dén narah titiyan nipun / sejanéhamaleswirang/purobaya...."

“....Itwastold thatYourMajestyPrinceGebang recalled his brother, the dead Salingsing. Then he went out by riding on a Sembrani horse, his vehicle, to find his brother's killer. Descending from the sky Prince Sutajaya immediately took the arrow and indended to revenge the defeat to Ki Purobaya ...." In this case, the name Sutajaya contained in Babad Sutajaya has a match with the existing of archive records and oral traditions. In other words, it showed that the figure known as Prinsdom van Gabang (Prince of Gebang) was Sutajaya and was a very real figure and had been existed in concrete history of the Archipelago.

The origin of Prince Gebang or Prince Sutajaya is not very clear. However, local sources from Cirebon state that Sutajaya was one of the Cirebon nobles who were descendants of Sunan Gunung Jati. In the compilation of the genealogy belonging to
Cirebon Palace, it was mentioned that Sutajaya was one of Sunan Gunung Jati's rebuttal. His lineage was connected through Prince Wirasuta who was Sutajaya's father, then connected to his grandfather Prince Swarga, and then connected with Prince Pasarean who was his great-grandparent, and the last as his canggah (great-great-grandchild) was Sunan Gunung Jati (Mukhtar, 2017). In addition, the family line relationship owned by Sutajaya was also recorded in a number of ancient Cirebon manuscripts, one of which was a manuscript of Kacirebonan Keraton collection which was estimated to be finished written in 1860. In the coded manuscript of KCR 04, it was said that Prince Wirasuta was Dipati Swarga and Queen Wanawati's third child. While his brother, namely Prince Mas, was a successor of Sunan Gunung Jati and Fatahillah as King Cirebon after the death of both (Irianto dan Sutaraharja, 2013). Although there is little difference in the placement of the names of their ancestors, as big or little brothers, at least two local sources indicate a certain agreement that Prince Sutajaya is a descendant of Sunan Gunung Jati.

Prince Gebang was known in the records of the colonial archives as one of the local rulers in the area of West Java. He was an important figure from Cirebon which was later appointed by the leadership of Batavia as one of the local kings in the territory that the VOC had just gained from Mataram after the 1677 agreement. Because of its noble status, the area that controlled by Prince Gebang received special treatment from the governor-general of Batavia and was named as Principality of Gebang.

\section{EXPLORING BABAD SUTAJAYA MANUSCRIPT}

\section{Description and Identification of The Manuscript}

The owner of the Babad Sutajaya manuscript is Raden Hasan Ashari bin R. Suyono and the script was kept in the Pangeran Pasarean Museum, Gegunung, Sumber. Ashari got the manuscript from his father who also got it from his grandfather. So, the manuscripts owned by Ashari are objects that have been handed down from generation to generation. Based on his pedigree records, Ashari lineage is still connected to Sunan Gunun Jati, and the origin of aboth his parents are still from the Cirebon Sultanate.

The manuscript with the code number LKK_CRB2016_RHS005 is based on the manufacturer's paper. The condition of the manuscript is not very good because it is 
somewhat damaged and the ink is translucent, although the latter damage is not yet clear at the time of writing or after. The manuscript page is stitched with thread and the manuscript does not have a cover. The number of pages in this script is 104 pages, with the number of lines per page as many as 12 lines. The length and width of the script is $21 \mathrm{~cm} \mathrm{x} 17 \mathrm{~cm}$, with the length and width of the text about $18 \mathrm{~cm} \mathrm{x} 14 \mathrm{~cm}$.

\section{The Relevance of Manuscripts to Reveal the Images of Characters in History}

The word 'manuscript' is equivalent with word naskah (Bahasa Indonesian), al-nuskhah (Arabic), and handschrift (Dutch). The word is derived from the Latin word, manu and scriptus, means 'handwriting'. Although it comes from English word, the word manuscript has also been adopted and is known plurally as the word naskah. Because its mean as 'handwriting', the manuscript is interpreted as a handwritten document on media such as paper, papyrus, palm leaf, daluwang, animal skin, etc. (Tjandrasasmita, 2006). Related to this, Baried reveals that manuscripts are handwriting which holds various expressions of thoughts and feelings that are the result of a culture of the past, which generally contains stories, but anonymous and unpredictable years (Baried, 1994). The manuscript is one of the most authentic primary sources that can bring the distance between the past and the present. In this case, the manuscript can be used as a privileged shortcut access to reveal the intellectual and social history that occurred in the past (Fathurahman, 2010). In the context of the Archipelago, the manuscript is available in so many quantities with various characters, languages, materials, and themes.

However, the manuscript cannot be fully used as a historical source. This can happen because in general the manuscript is written long after the event, some even written without the number of years and without the name of the author (anonymous). Distant time intervals and the obscurity of the author's identity certainly makes the level of trust in the content of the manuscript become increasingly reduced. Therefore, in reading the manuscripts, especially to use them as a source of history, it takes certain professions and skills that are indeed focused and specialized on the field. Special profession in question is a philologist or a manuscript scholar whose expertise can be accounted for. By the competence they possess, the philologist usually takes the portions which is logical or rational in the manuscript to be used as the material of historical study. In Cirebon region, manuscripts are stored in many places, ranging from those in the palace to those in the community. Manuscripts in this last environment are found in many circles. As one of the most important places, Cirebon contains many historical relics. The forms of cultural heritage and civilization of the past that exist in this region are also very varied, not only in the form of physical buildings such as mosques, palace palace, and colonial government buildings, but also to the non-physical form as well as art, customs and unique or distinctive traditions, which may exist only in the area of Cirebon. Thus, it is not surprising that in their works, many foreign scholars revealed the advantages of Cirebon. For example, Pigeaud who declares Cirebon as one of the centers of coastal literature (Pigeaud, 1967) or de Graaf who recognizes Cirebon as the center of the spread of Islam in West Java (Graaf, 1989).

As a manuscript originating from the Cirebon region, Babad Sutajaya is one of the manuscripts that can be used as a source to reveal the figures studied in this study, Prince Gebang. Whereas the manuscript was not made contemporary with the life of the prince, but the contents contained in the manuscript obtained from oral tradition that developed in the local community. And although oral traditions are limited to oral testimonies transmitted verbally from one generation to the next (Vansina, 1972), the writing of it becomes important and will be recorded in standard for a longer period of time. However, the Babad Sutajaya, which is perpetuated through the manuscript tradition that exists in the community, has its own advantages when compared with the archive source written by the colonial or foreign parties. Through the manuscript, an in-depth image of Prince Gebang's figure will be more expressed, especially the image that stems from the view of the local community. As well as the history of life and the Greek intellectual traditions that can be examined by translation and study of manuscripts found in the West, the life history of Prince Gebang can also be expressed through the research of this chronicle text.

The first text of Babad Sutajaya, which tells the story of Prince Sutajaya's action in fulfilling King Cirebon's command, gives a different nuance, especially related to the prince's personality, his fighting spirit, and his greatness. By giving more portion to Sutajaya and its magical superiority, it is indirectly the text of a historical novel that always demands 


\section{The Image of Prince Gebang in Babad Sutajaya Manuscript}

historical authenticity, historical faithfulness, and historicity of local color (Lukacs: 1974). It certainly makes the character of the times recorded in the manuscript of Babad Sutajaya into something authentic and interesting to be expressed in the light.

\section{THE IMAGE OF PRINCE GEBANG IN THE BABAD SUTAJAYA MANUSCRIPT}

\section{Prince Gebang as the noble of Cirebon Palace}

As mentioned earlier, Prince Gebang is believed to be a figure who came from the environment family of the Cirebon Sultanate. The records of the colonial archives that mention the territory of Gebang as a center power which is titled as 'kepangeranan' orprincipality, and of course it is certainly have certain basis and consideration. It is impossible if the mention is without any background, unless it has a clear historical line.

Babad Sutajaya itself, very clearly indicates that Prince Gebang or Prince Sutajaya is a royal palace who has a high status for being able to sit with King Cirebon in royal meetings. On page 2 of the manuscript, narrated that in a meeting to take action against another kingdom, Prince Gebang sat down with the King of Cirebon: "....wonten kandha / wahu kang ginnurit / kang kocappa / wahu kanjeng sultan / srinnarannatta gerraggé / pangéran gebbang hakumpul / kasepuhan sammiya linggih / hanenggih pangéran papak / sedhaya hakumpul / hanenggih kakasih hira / suttajaya / lawan pangéran sallingsing / wahu kinén mariksaha ...."

"....There is a story in which it is written that once upon a time Kanjeng Sultan and Prince Gebang gathered and the old man who sat was Prince Papak. Among those who gathered, there was Sutajaya, together with Prince Salingsing, who was then ordered to check the eastern region...." The opportunity to be able to sit with a ruler is certainly not an easy thing to do for the conditions at that time. Especially if the opportunity is intentionally carried out on the wishes of the king or used as a stage for someone to receive a request from the king. In such meetings, the king usually sits in the middle of two ranks of noble royal or high-rank of the sultanate. The closer to the king, the more important the position of the person. Conversely, if the position of the seat further than the king, then the status of the person is lower than the other.
In addition, in other parts of the text in page 18 , it is also explained that the seat of Prince Gebang is parallel to the king: “....sakéca génira lungguh / hing cerbon jeng sultan naji / sinéba para satriya / ponggawa lan para mantri / handhér hana hing paséban / bedhaya sami mareki // semana gunem cinatur / kalih sutajaya mangkin / hora ganti kang kocapa / sapraptané sunan adhi / kaliyan padmanegara / hanulya tetanya linggih...."

“...While sitting comfortably, Sultan Aji Cirebon was later visited by the knights, Ponggawa and Mantri. They sat in line at Paseban, kneeling close together. At that time, while the Sultan was chatting with Sutajaya, both Sunan Adi and Padmanegara came. After giving salute to the Sultan, then both of them sat down and gave the report...."

Equality is also written on page 30, thefollowing: “...susunan linggih satata / wahu lawan kanjeng gusti / sutajaya radén padma / hanjajar linggih hing korsi / kang sareng lan sultan naji / hing negara carbon nagung / kanjeng sultan sukansukan / kang langkung bungah negari / raja roban / kang nami raja durbiksa...."

“....Sunan Kalijaga sits together with Kanjeng Gusti, Prince Sutajaya and Prince Padmanegara sitting in chairs. They seemed to rejoice over King Roban's submission, which name as Raja Durbiksa...."

The sitting position in almost equivalent to the king indicates that Prince Gebang is not an ordinary person in the palace of Cirebon. It shows that he was included in the group of people who were considered the closest to the king. Through the two narrative sections listed in Babad Sutajaya, it can be seen that Prince Gebang is a noble elite of Cirebon who has a high position in the middle of the kingdom.

\section{Prince Gebang as a Powerful Man}

In traditional script writing or babad, the ability of a central figure is always imaged with great, full of imaginary and miraculous elements. Generally, his ability is above the average ability of other ordinary people. Even so, the image of a character who is considered excessive can also have other meaning that is more rational. One of the capabilities imaged by Prince Gebang is to travel by flying in space, even at incredible speeds. In page 3 of the manuscript, it is written that: 
"...sutajaya hangandika harris / hing pangéran salingsing ta sirra / payu mangkatta dhén nagé / aja bareng lawan nisun / ngambaha sitti prattala / hisun ngamba majagantang / hing bésuk tinnemu / hiku lamn karréppotan / matur nembah / wahu pangérran sallingsing / hangamba sitti prattalla // sutajaya hangamba wiyatti / nitti kuddha sambarranni hika / hakebat nyerrig lakunné / hing geganna sampun munjuk / sampun lepas tiyang kekalih...."

“...Sutajaya said to Prince Salingsing, "Let us go immediately, but your steps are not with me. You walk through the earth while I am alone through the clouds. One day we meet when we are in distress. "Prince Salingsing gives honor, then he goes on earth. Sutajaya sped into space by riding a samberani horse, his mounts moving rapidly up into the sky. The two men had left...."

In another section of the manuscript on page 14, the prince's flying ability with his horse is also greatly illustrated: "...sutajaya / nerajang sing ngawangngawang / cumlorot lir tapak kangin / hangamba wang - ngawang / tur sarwi niti kudha / hanulya dipun kembuli / raja dhurbiksa / sinépak tiba kewalik // nulya gendring / playuné raja dhurbiksa / singidan ning kenya puri / kocap puniki / hiya ta sampun nical / karsa nira hanglelarri..."

"...Prince Sutajaya displayed from the sky on a brave horse, so he leap like a typhoon. King Durbiksa was kicked off. King Durbiksa then fled to Kenya Puri, told the King then had disappeared mixed with the demon environment (bangsa halus)...."

In addition to having the linuwih ability, Sutajaya was also portrayed as a person who has skills in playing arrow weapons. Even according to this manuscript, he killed Cirebon's archenemy by archery. On page 5 of Babad Sutajaya, it is narrated that: "...hanitilimandhénjugjug/kawurbinaktang sanjata / tiba ing gunung cendhinni // wus silr dhénning ngutarra / purobaya binaktang sanjata hangin / tumiba segara gunung / tiba hing gunung kumbang...."

“....By riding the elephant of Prince Sutajaya releasing the heirloom arrows towards the enemy, the arrow of the target $\mathrm{Ki}$ Purobaya drifted by the arrow of the fall on Mount Cendini. Blown by the North wind,
Ki Purobaya flew carried away by a wind weapon and then fell on Mount Kumbang...."

According to Babad Sutajaya, Prince Gebang also has advantages in the ability of his hands. The prince's blow was considered so frightening that Roban's Royal guard forces could not resist it. The enormity of the blow is described in pages 6 to 7 of the manuscript, as follows: "...pattih bradhangga bramatyan / ballika hisun larrangi // cinnandhak sira rinujag / suttajaya / hakebat nulya ngembuli / prajurité samya lebur / ki pattih wus tumandhang / tur tangginas / ki patih hing tandhang ngipun / cinandhak wahu ki patya / gineblag nulya ngemasi // akéh perang padha rowang / kang sawenéh / padha ngungsi negari / ana ngungsi wana agung / anna kang mundhur dhibéndhang / kang kabrannang / anna remuk hendhas sipun / anna tattu dhadha nira / sawenéh tatu hing gigir // gégéré kadhi hampuwan / negri robban / pattih bradhangga ngemasi / kappidhangetting sang prabu / lawan prabu cakraninggrat / salling tunjang / wahu perang hing ngacucuh / lan pangéran sutajaya / raméh perang salling ngukkih // cakraninggrat mundhur ragelar / kawarnaha / jeng sinuhun ningali / cakraninggrat pan lumayu / sigra sinuhun mangkurat / suttajaya / hasruh dhénira hangamuk / mangkurat pan nora nyangga / nulya wangsulling negari..."

"....Ki Patih ordered the soldiers to arrest, but Sutajaya served and even attacked the soldiers to melt apart. Ki Patih deftly traveled, Sutajaya moved quickly to attack Ki Patih with a blow until he died. The atmosphere became chaotic, so many people fought with their own friends while others fled the country. There were also those who went to the big forest, there were also soldiers who retreated, some whose heads were crushed, injuries to the chest or back. Even though Roban became a rumble, the news spread that Ki Patih Bradhangga had died. This news was heard by Prabu Roban and Prabu Cakraninggrat, so there was a lot of war going on with Prince Sutajaya. Cakraninggrat retreat from the field of jurit, told Kanjeng Sinuhun Mangkurat see Cakraninggrat run, Sutajaya increasingly fierce. Sinuhun Mangkurat feels unable to resist the opponent's tantrum then return home......"

With these three powers, namely flying in 


\section{The Image of Prince Gebang in Babad Sutajaya Manuscript}

space, archery, and blows, Prince Sutajaya was described as a winner in the war between the Kingdom of Cirebon and its enemy. Although the strong impression that arises when first reading the manuscript is a description which that is full of too high imagination, in fact these three abilities lead Sutajaya to become an important figure in the history of Cirebon. Flying in the sky is an illustration that implies speed, ability that cannot be owned by many people. With fast action, Sutajaya can perform its duties well. Meanwhile, archery's ability to indicate that Sutajaya is a person who always consider the accuracy. Not only in each of his decisions when deciding on the war, but also when he built the Principate of Gebang and cooperated with the VOC. While the ability of a strong punch, is a representation of strength owned by Sutajaya is not an ordinary strength. That ability is not only an individual ability, but also a group. At least it shows that Sutajaya is a person who has a great personality so that it can muster the power which can be utilized for self-need and the power that he builds.

\section{Prince Gebang as the Beneficiary}

In addition to the mystery of the origins and character of Prince Gebang, the process of life that led the prince to become ruler of Gebang was still shrouded in many questions. Although the oral tradition that developed in the midst of society already mentions that it is the result of his success in destroying the forest which is controlled by many demons (or dedemit) through the power of the kris named Setan Kober, in fact the oral story is not too rational and also not trusted by many circles. Regarding this, Babad Sutajaya has a slightly different view but the authenticity must be further researched. In the manuscript, Gebang land rights granted by the ruler of Cirebon due to the success of Prince Sutajaya in carrying out the task of fighting the Roban Kingdom and bringing the enemy troops as evidence in front of the king. On page 28 of the manuscript, the process of transporting prisoners of war of the Purobaya troops, who are enemies, is described as follows: "....bubaré jumadhilawal / sutajaya sunan nadhi / radén padma anang wuntat / boyongané dhén giringi / hangiringaken dhedhemit / purobaya gunung kidhul / cendhini lan pemancingan / bubar segala dhedhemit / sukansukan / sedhalan pan susurakan...."

“...In early Jumada al-awwal, wadyabala Cirebon returned. Sunan Kali, Prince
Sutajaya, and Prince Padmanegara followed from behind. In addition to carrying loot, they also took Purobaya, and Cendini. The demons broke up, and they along the way cheered...."

As the success of hard work against forces led by Purobaya and King Roban, eventually each of the figures who have a share in the war was awarded by King Cirebon. The reward for the royal court's efforts was enshrined in page 30 of the Sutajaya Babad manuscript with the following details:

“....kocapa kisutajaya/kelawanpadmanegari / lawan sunan kalijaga / andhér alinggih hing korsi // siweg nampa gajih wahu / si padma dhadhi bopati / sutajaya dadi sultan / kanoman tah negari / wonten negari gebang / puputra dhalem kaboni // sigegen ning dhalem magung / kang wonten gebang puniki / nami wahu sutajaya / kelawan padmanegari / kang wonten dhusun telaga / hing carbon ki sunan kalih...."

"....It is told that Ki Sutajaya, Padmanegara and Sunan Kalijaga were chatting while sitting in chairs. They received their rewards. Padmanegara became a regent or Bopati. Sutajaya became the Sultan Anom in Gebang who later had a heir named named Dalem Kabon. Dalem Agung decided that person who would rule Gebang was Sutajaya. Meanwhile, Padmanegara inhibited Dusun Telaga and Sunan Kalijaga in Cirebon....."

With this explanation, it is increasingly clear that the origin of the Gebang pioneering area came from the granting of land carried out by the King of Cirebon to Pangeran Sutajaya. The name Gebang is attached to the area because the area is overgrown by many gebang trees. Meanwhile, the name of Prince Gebang was attached to Prince Sutajaya because he was the ruler of the Gebang region that had been building since the first area.

\section{CONCLUSION}

Like most other historical literary works, Babad Sutajaya also shows many other things about the figure of Prince Gebang. Not only does it describe the establishment of Gebang region, but the manuscript also gives the names to a number of figures who helped the life of Prince Gebang (Pangeran Gebang). Nevertheless, all the details contained in the manuscript as a source of history were not used, because in essence the manuscript is 


\section{Anwar Sanusi, Tendi}

a literary work that is nothing but a product of thought and imagination, and is not intended to be a factual historical narrative. Amidst the advantages and disadvantages of the manuscript as a source of history, the study showed that the image of Prince Gebang on Babad Sutajaya is as an important figure, who came from the royal court of Cirebon. In addition, the manuscript also illustrates

\section{REFERENCES}

Baried, S. B. (1994). Pengantar teori filologi. Yogyakarta, Indonesia: Fakultas Sastra Universitas Gajah Mada.

Fathurahman, O. (2010). Filologi dan Islam indonesia. Jakarta, Indonesia: Kementerian Agama RI, Badan Litbang danDiklat, Puslitbang LekturKeagamaan.

Fernando, M., \& Radin. (2013). "Sebuah daftar masa lalu terkait desa, kepala desa, rumah tangga, upeti dan penghasilan di Priangan, Jawa Barat, 1686". Dalam: Harta Karun. Khazanah Sejarah Indonesia dan Asia-Eropa dari Arsip VOC di Jakarta. Dokumen 11. Jakarta, Indonesia: Arsip Nasional Republik Indonesia.

Graaf, H. J., \& Pigeaud T. G. (1974). De Eerste Moslimse Vorstendommen op Java, studien over de staatkundige Geschiedenis van de 15 de en 16 de Eeuw. VKI vol. 69. 's-Gravenhage: Martinus Nijhoff.

Irianto, B. \& Sutarahardja, T. (2013). Sejarah Cirebon: Naskah Keraton Kacirebonan (Alih aksara dan bahasa teks KCR 04). In: Zaedin M M, \& Darussalam P, editors. Yogyakarta, Indonesia: Deepublish. Lukacs, G. (1974). The historical novel.
Prince Gebang's abilities and reveals how he gained the territory of Gebang as his controlled area. By those evidences, Babad Sutajaya can be considered as an important medium for people and historical enthusiasts of Cirebon region to be able to recognize Prince Sutajaya (Pangeran Sutajaya) or Prince Gebang (Pangeran Gebang) more deeply.

London, United Kingdom: Merlin Press. Mubyarto. (1992). Tanah dan tenaga kerja perkebunan: kajian sosial ekonomi. Yogyakarta, Indonesia: Aditya Media. Pigeaud, Th, G. T. (1967). Literature of Java: catalogue raisonne of Javanese Manuscripts in The Library of the University of Leiden and Other Public Collections in the Netherlands. Vol. I. Sjamsuddin, H. (2007). Metodologi sejarah. Yogyakarta, Indonesia: Ombak.

Stapel, F. W. (1935). Corpus Diplomaticum Neerlando-Indicum. Vierde Deel. 'S-Gravenhage: Martinus Nijhoff.

Tjandrasasmita, Uka. (2006). Kajian naskahnaskah klasik dan penerapannya bagi kajian sejarah Islam di Indonesia. Jakarta, Indonesia: Puslitbang Lektur Keagamaan, Badan Litbang dan Diklat, Departemen Agama.

Vansina, J. (1972). Once upon a time: oral traditions as historyin Africa", dalam Felik Gilbert and Stephen R. Graubard (eds.), Historical Studies Today. New York, United States: W.W. Norton \& Company. 